\title{
First record of Curvella sikkimensis (Reeve, 1850) (Pulmonata: Subulidae: Subulininae) from Nepal and its reproductive organs
}

\author{
Prem Bahadur Budha \\ Central Department of Zoology, T.U., Kirtipur, Kathmandu, Nepal \\ E-mail: pb.budha@gmail.com
}

\begin{abstract}
The genus Curvella contains about 50 described species from the tropical world. Out of them four species are known from north eastern India. The original descriptions of all known species are based on the shell characters only. The reproductive anatomy of any species of the genus is still unknown. This is the first evidence on the reproductive anatomy on Curvella sikkimensis from Nepal.
\end{abstract}

Key words: Albumen gland, Genital organs, Reproductive anatomy

\section{Introduction}

The genus Curvella (Chaper, 1885) belongs to the stylommatophoran land snail family Subulinidae. There are approximately 50 species distributed in tropical countries such as South Africa, India, southern part of China and South East Asia (Schileyko, 1999). All known species were identified based on the shell characters and their size varies considerably from 3 to $27 \mathrm{~mm}$ (Pilsbry, 1906; Gude, 1914; Verdcourt, 2002). Only four species C. sikkimensis (Reeve, 1850), C. khasiaca (Godwin-Austen, 1872), $C$. munipurensis (Godwin-Austen, 1872) and C. blanfordi (Gude, 1914) were reported from North East Indian states: Assam, Arunachal Pradesh, Meghalaya, Nagaland, Sikkim and West Bengal (Gude, 1914; Ramakrishna et al., 2010). Budha et al. (2015) reported $C$. sikkimensis from Ilam district.

Reeve (1850, Pl. 87, Fig. 651) described Bulimus sikkimensis (= C. sikkimensis) from Darjeeling, India based on the juvenile shell from Benson's collection. The original description of the species includes "Shell ovate, somewhat inflated, spire rather short, obtuse at the apex, whorls 4 in number, the last much the largest, concentrically finely striated, sutures impressed, columella slightly twisted, thinly reflected, aperture oblong, slightly sinuated at the upper part; pale olive, semitransparent".

The systematic position of this genus is still unclear due to no published reproductive anatomy and phylogenetic studies. The present study shows the animal and the reproductive anatomy of $C$. sikkimensis providing the first evidence to compare its anatomical characters with other genera of the family Subulinidae.

\section{Materials and Methods}

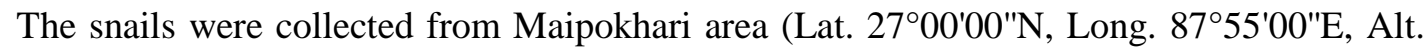
$2100 \mathrm{~m} \mathrm{msl} ; 24$ shells and 4 specimens, 29.X.2010. leg. P.B. Budha), Ilam district, eastern boarder of Nepal with India close to Darjeeling. Shells and specimens were found at the 
base of Cryptomeria japonica tree under thick layer of soft bark and fallen log. Collected specimens were sorted into live individuals and shells. Live specimens with well developed white ephiphragm were drowned into water to activate animal. Photographs of snail and its epiphragm were taken with Nikon D50 camera in the field. Live individuals were drowned into water for 24 hours to kill the animal with proper stretching the body. Drowned individuals were preserved in $90 \%$ ethanol which was replaced again within a week. Collected samples were brought to the Central Department of Zoology for anatomical work. Preserved animals were dissected and reproductive parts were separated, photographed and illustrations were traced from the photographs of the reproductive parts. Reproductive anatomy of Subulina octona given in Pilsbry (1906) was traced in the Macromedia Flash 8 software. Collected specimens were deposited at Central Department of Zoology Museum of Tribhuvan University (CDZMTU), Kirtipur, Kathmandu, Nepal.

Abbreviations used: AG - Albumen gland, AO - Amatorial organ, BC - Bursa copulatrix, GO - Genital orifice, GS - Gamytolytic sac, HD - Hermaphrodite duct, Otd - Ovotestis duct, OV - Oviduct, P-Penis, PP - Penial papilla, PR - Penial retractor, SO - Spermoviduct, V - Vagina, VD - Vas deferens.

\section{Results \\ Shells characteristics}

Shell turretedly ovate, subobtectly perforated, nearly closed by reflected columellar lip, yellowish white, semitransparent, apex obtuse (Figs. 1A, 1B), embryonic whorl one, smooth lined with spiral striae, other whorls show closely set fine radial ribs decussated with spiral linings forming granulated ribs (Fig. 1C). Suture deep, height of the body whorl is nearly $1.5 x$ longer than other whorls. Aperture oblong, peristome thin, columellar margin thin and abruptly reflected toward columella nearly closed the columellar opening. Shell height $(\mathrm{N}=4)$ 16.6-19.2 mm, width 6.2-7.0 mm, whorls 6.5.

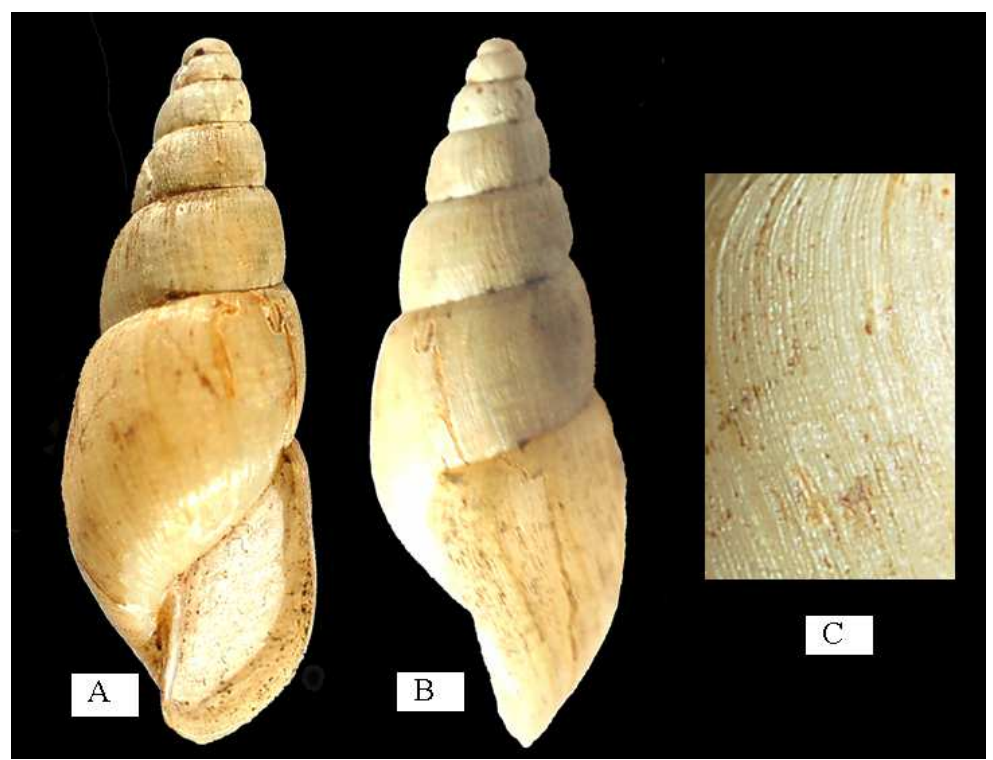

Figure 1. Shell of C. sikkimensis (height $17.3 \mathrm{~mm}$ ). A. Frontal view showing temporary operculum (epiphragm) attached to the aperture. B. Side view. C. Shell surface showing radial sculptures. 
Live animal (Fig. 2A) whitish, body weakly papillated, posterior tail portion pointed in fully extended animal, eye muscles distinguished with slightly dark coulour under the skin of the anterior body. Eye tentacles darker than the body with black eye spot at the tip. Epiphragm transparent with pointed upper end connected to the parietal lip, columellar lip area straight and outer margin rounded forming slightly kite shaped structure (Fig. 2 B).

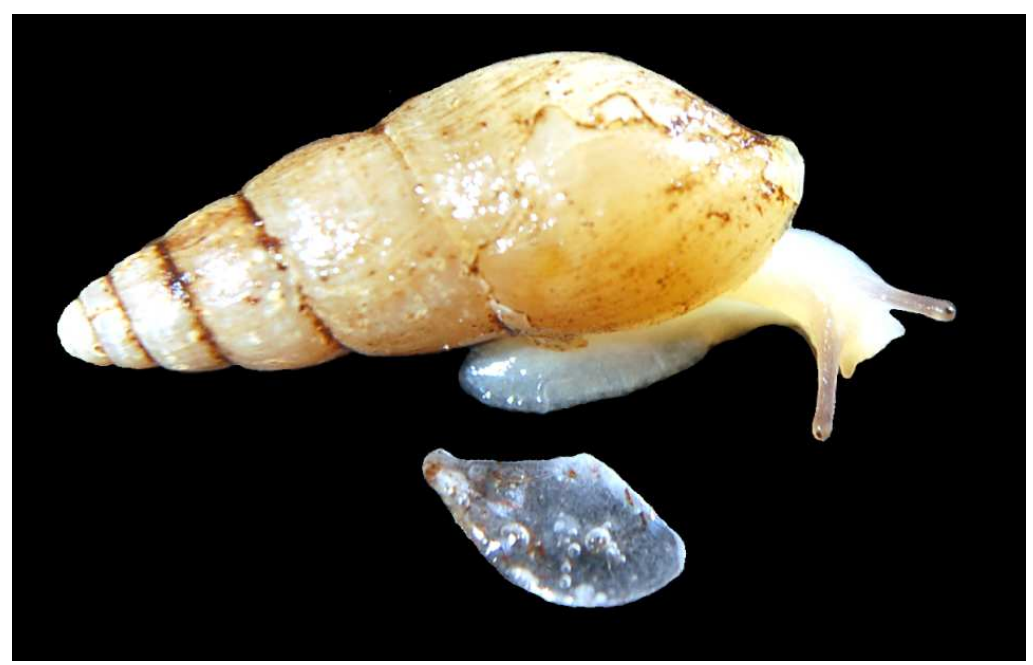

Figure 2. Live animal. A. Animal in motion. B. Epiphragm

\section{Reproductive anatomy}

The vas deferens is wide tube nearly equal to oviduct diameter entering to the side of the penis at the middle part of the penis (Fig. 3B). Penis is wide and short. The penial retractor attached to the free end of the penis. Gametolytic sac is slightly longer than the oviduct and swollen at the free end. Oviduct is long nearly equal to the spermoviduct. Albumen gland is large. Vagina wide and short (Fig. 3A). Interior of the penis is papillated (Fig. 3C).

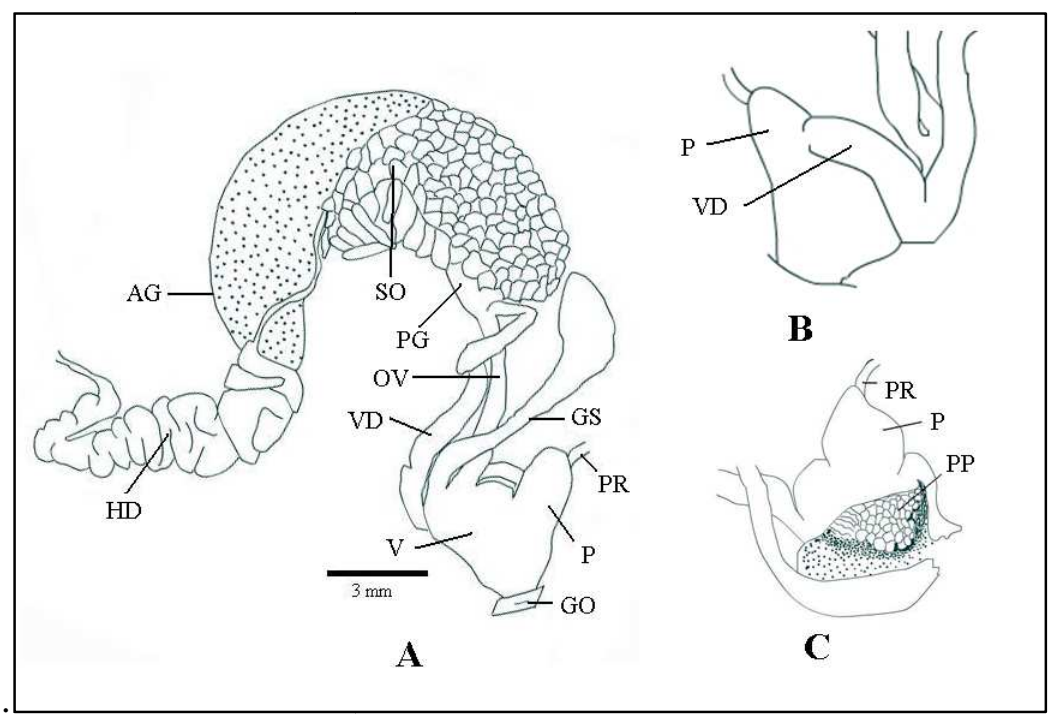

Figure 3. Genital organs of $C$. sikkimensis. A. General view of genital organs B. Showing vas deferens connecting to the penis. C. Interior of the penis. 


\section{Discussion}

The genus Curvella shows some affinities with Opeas however, the boundaries of Curvella and Opeas are also unsettled. Some species identified as Curvella in old manuscripts i.e., Pilsbry (C. shimbiense and C. alabastrinaare) are assigned to Opeas lamoense (Melvill \& Ponsonby, 1892). Some of museum species labeled as Curvella belong to Opeas, Pseudopeas or Euonyma (Pilsbry, 1906).

Curvella was included within the family Achatinidae and subfamily Stenogyrinae by Gude (1914) in 'The Fauna of British India'. But, Schileyko (1999) re-classified Curvella under the family Subulinidae and subfamily Subulininae along with Allopeas, Prosopeas, Prosopeas, Subulina, Lamellaxis and Pseudopeas. However Opeas is separately classified as a distinct subfamily Opeatinae.

At present the systematic position of Curvella is still uncertain. Anatomical data are still lacking on many of the genera and very few have been sufficiently investigated. There is a great variation in the penial structure in Subulinidae, particularly the subfamily Subulininae where the Curvella is placed viz. in Subulina octona penis is small and simple with terminal retractor as in Rumina (Pilsbry, 1906) (Fig. 4).
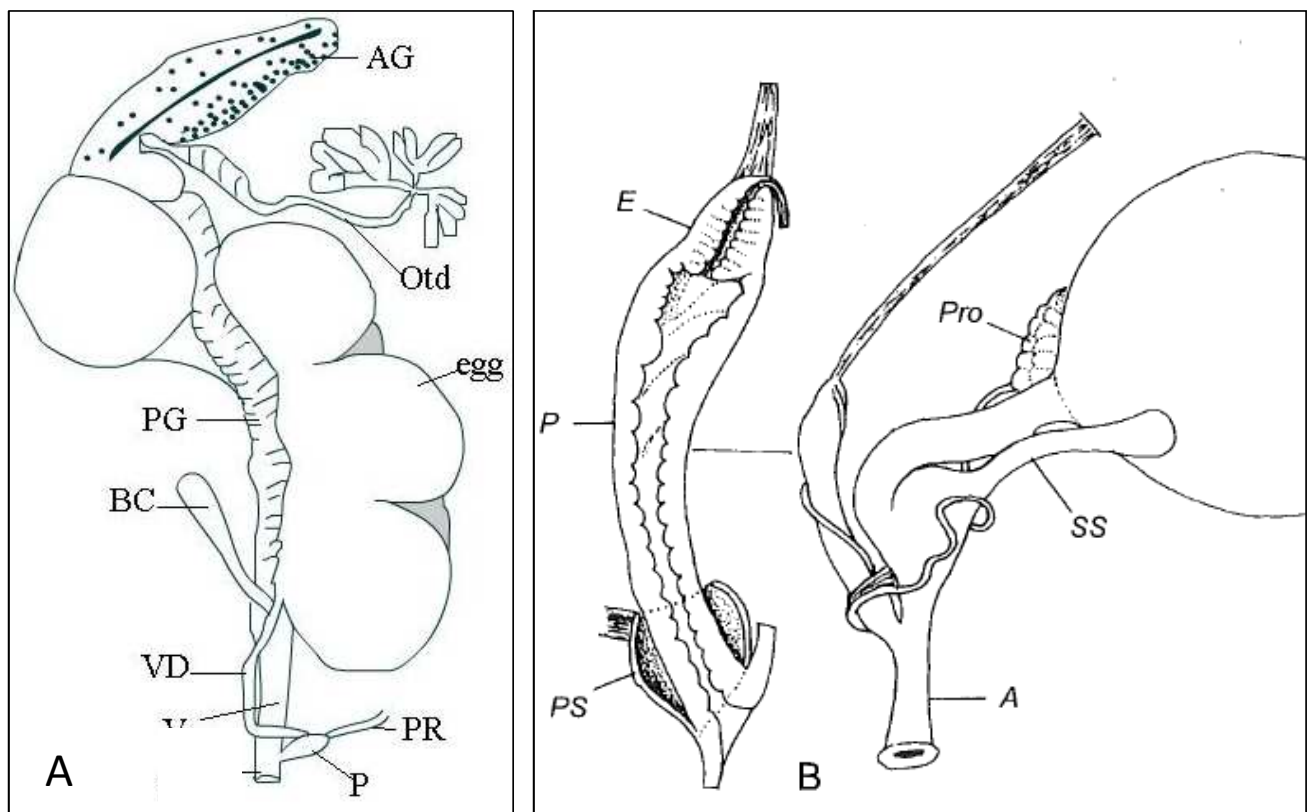

Figure 4. Reproductive anatomy A. Subulina octona (redrawn from Pilsbry, 1906, Pl. 50, Fig. 24) B. Opeas pumilum (L. Pfeiffer, 1840) (from Schileyko, 1999).

The penis in Paropeas is narrow, long and muscular which is basally closed in penial sheath (Naggs, 1994). It is still unclear whether the penial structure has the strong basis of shifting generic position in different subfamilies or the shell is the prominent character. Unless the reproductive anatomy of other species are known better to follow the old relationship with Opeas and temporarily place Curvella under Opiatinae rather than Subulininae based on the reflected columellar lip in the shell character and simple penis. 


\section{References}

Budha, P.B., F.N. Naggs \& T.B. Backeljau 2015. Annotated checklist of terrestrial mollusks of Nepal. Zookeys 492: 1-48.

Gude, G.K. 1914. Mollusca-II (Trochomorphidae-Janellidae). The fauna of British India including Ceylon and Burma. Today and Tomorrow's Printers and Publishers, New Delhi. 518p.

Melvill, J.C. \& J.H. Ponsonby 1892. Descriptions of seventeen new terrestrial molluscs from South or Central Africa, in the collection of Edgar L. Layard, Esq. Annals and Magazine of Natural History, Series 6, 9: 87-94.

Naggs, F. 1994. The reproductive anatomy of Paropeas achatinaceum and a new concept of Paropeas (Pulmonata: Achatinoidea: Subulinidae). Journal of Molluscan Studies 60: 175-191.

Pilsbry, H.A. 1906. Structure and systematic with illustrations of the species. Pulmonata: Achatinidae, Stenogyrinae, Coeliaxinae, vol. 18, series 2. Philadelphia, Conchological Department, Academy of Natural Sciences, Philadelphia.

Ramakrishna, S.C. Mitra \& A. Dey 2010. Annotated checklist of Indian land mollusks. Records of Zoological Survey of India, Occasional Paper No. 306: 1-359. Zoological Survey of India, Kolkata.

Reeve, L.A. 1949-50. Illustrations of the shells of molluscous animals. Conchologia Iconica 5: 362.

Schileyko, A.A. 1999. Treatise on recent terrestrial pulmonate mollusks, part 4. Ruthenica, Supplement 2: 437-564

Verdcourt, B. 2002. Two new species of Curvella Chaper (Gastropoda,Pulmonata, Subulinidae) from the East Usambara Mts., Tanzania. Basteria 66: 107-112. 